\title{
Study of Yield Gap Analysis among Paddy Growers in Plain Zone of Chhattisgarh State
}

\author{
Vijay Kumar Patel*, B.C. Jain, A.K. Koshta, V.K. Choudhary and M.R. Chandrakar
}

Department of Agriculture Economics, Indira Gandhi Krishi Vishwavidyalaya, Raipur, Chhattisgarh, India

*Corresponding author: vijaykumarpatel@live.com

\begin{abstract}
The present study analyses the total yield gap in paddy crop in to three different gaps viz. yield gap-I, yield gap-II and total yield gap. The study based on primary as well as secondary data was carried out in three districts of plain zone namely Rajnandgoan, Mahasamund and Dhamtari districts. At the second and third stage of sampling, two blocks and two villages were selected from each district and each block, respectively to constitute a total of 6 blocks and 12 villages. Primary data were collected from a sample of 240 paddy farmers (20 from each village) through personal interview method and secondary data were collected from respective districts of K.V.K in crop year 2016-17. Most of the sample farmers were growing Rajeshwari (IGKV R-1) variety of paddy crop. Yield gap analysis shows that 13.22 per cent yield gap was estimated between potential and potential farm yield where as yield gap between potential farm yield and actual yield was estimated overall 20.00 per cent. Index of realized potential farm yield was observed 71.78 per cent on marginal farms to 89.44 per cent on large farms with an overall average of 80.00 per cent. It may be inferred from the study that the use of important variable has to be carefully extended by the paddy farmers to minimize the yield gap. Besides, the input supply of quality inputs viz. seeds, farm yard manure, irrigation and plant protection measures on different categories of farms may help to reduce the yield gap of the crop on the one hand and raise the income of the cultivators on the other.
\end{abstract}

Keywords: Yield gap, potential yield, Constraints

Rice is a staple food for more than 3.5 billion people worldwide, around half of the world's population (Babatunde et al. 2016). The food grain production in India during 2011-2012 reached an all time high of 259.32 million tones and the production of paddy during the year was 104.3 million tones accounting for about 29 per cent of the global production (GOI, 2013). Despite these achievements, the productivity of rice in India is comparatively low and ought to be raised for making the production sufficient to meet the needs of the growing population. With limited scope for expansion in area, productivity enhancement needs to be the major approach for rice which is the choicest crop of millions of farmers not only for their livelihood security but also for meeting the food security needs at the household level. Although the growth in yield of wheat and rice in major growing states of India has been slowing down, the actual yields are far below the agro-ecologically attainable yields, which suggest that there are still considerably bridgeable yield gaps in India (FAO, 2013). Closing the rice yield gap aims not only to increase rice yield and production but also to improve the efficiency of land and labor use and reduces production costs. To maintain national food security there is a need to increase rice production to sustain self sufficiency.

Yield gap is the difference between the maximum attainable yield and the farm level yield. Maximum attainable yield is the yield of experimental or on farm plots with no physical, biological and economic constraints and with known management practices at a given time and in a given ecology. Farm level yield is the average farmers yield in a given area at a given time in a given ecology. Yield gap has two components. The first component cannot be narrowed or is not exploitable because it is mainly 
due to factors that are non transferable such as environmental conditions. The second component is mainly due to difference in management practices. Yield gap II is manageable and can be bridged by deploying more efficient research and extension services.

Chhattisgarh state is recognized as rice bowl in India. Rice is mainly grown in kharif season in the state. The mono-cropped rain fed rice farming system is most prevalent in the state with area and production of 3.70 million hectare and 4.19 million tons respectively and productivity 1322 $\mathrm{kg}$ per hectare which is very low in comparison to national productivity of rice during 2015-16. (Economic Survey of Chhattisgarh 2016-17). Keeping above background in the mind, present study was conducted with the following specific objectives:

1. To estimate ion the magnitude of yield gap.

2. To identify the constraints responsible for yield gap in paddy cultivation as perceived by the farmers.

\section{MATERIALS AND METHODS}

In order to evaluate the objectives of the study, a multistage stratified random sampling technique was adopted. The present study was conducted in Rajnandgoan, Dhamtari and Mahasamund districts of plain zone of Chhattisgarh state. These districts have first, second and third place respectively in the area under rice crop. Multistage Stratified random sampling technique was adopted for selection of blocks, villages and sample farmers. At the second and third stage of sampling, two blocks and two villages were selected from each district and each block, respectively to constitute a total of 6 blocks and 12 villages. Primary data were collected from a sample of 240 paddy farmers (20 from each village) through personal interview method and secondary data were collected from respective districts of K.V.K in crop year 2016-17.

\section{Analytical tools}

\section{- Total Yield Gap =}

\author{
Potential yield (Yp) \\ (Yield realized at research station) \\ Actual yield (Ya) \\ (Yield realized on farmer's field)
}

To quantify the percentage of yield gap, the following equation was used in the present study.

$\mathrm{Gyp}=\mathrm{Yp}-\mathrm{Ya} / \mathrm{Yp} \times 100$

- Yield gap $\mathbf{I}=$

Potential yield $(\mathrm{Yp})$ -

Potential farm yield (Yd)

(Yield realized on demonstration plots)

- Yield gap II = Potential farm yield (Yp) Actual yield (Ya)

- Index of Yield Gap (IYG)

It is the ratio of difference between the potential yield (Yp) and the actual yield (Ya) to the potential yield, expressed in percentage.

$$
\mathrm{IYG}=[(\mathrm{Yp}-\mathrm{Ya}) / \mathrm{Yp}] \times 100
$$

- Index of Realized Potential Yield (IRPY)

It is the ratio of the actual yield (Ya) to the potential yield (Yp), expressed in percentage.

$I R P Y=(Y a / Y p) \times 100$

- Index of Realized Potential Farm Yield (IRPFY)

It is the ratio of the actual yield (Ya) to the potential farm yield expressed in percentage.

$$
\mathrm{IRPFY}=[(\mathrm{Ya} / \mathrm{Yd})] \times 100
$$

\section{RESULTS AND DISCUSSION}

Table 1 presents the yield performance of paddy (variety IGKV R-1) under the different field situations. It could be observed from the table1 that there existed a sizeable gap in the paddy (variety IGKV R-1), productivity on research station (potential yield),demonstration yield (potential farm yield) and the sample farmers field (actual yield). Paddy crop yield-realized on the research station $57.50 \mathrm{q} / \mathrm{ha}$ and on demonstration plots $49.90 \mathrm{q} / \mathrm{ha}$ which were sufficiently higher than on farmers fields $39.92 \mathrm{q} / \mathrm{ha}$.

Higher yield levels on research stations and demonstration plots were attributed to the fact that the experiments are conducted on scientific lines and are equipped with all the resources including the technical input on the research stations, while the demonstration traits are carried out under the Supervision of agricultural Scientists. 
Table 1: Yield level released and the estimated yield gap under the different size of holdings

\begin{tabular}{|c|c|c|}
\hline \multirow{2}{*}{ S1. No. } & Particulars & Yield q/ha \\
\hline & $\begin{array}{l}\text { Potential yield } \\
\text { (Research station yield) }\end{array}$ & 57.50 \\
\hline 2 & $\begin{array}{l}\text { Potential farm yield } \\
\text { (Demonstration plot's yield) }\end{array}$ & 49.90 \\
\hline \multirow[t]{5}{*}{3} & Actual yield & 35.82 \\
\hline & a. Marginal Farms & 37.64 \\
\hline & b. Small Farms & 41.58 \\
\hline & c. Medium Farms & 44.63 \\
\hline & $\begin{array}{l}\text { d. Large Farms } \\
\text { e. Overall }\end{array}$ & 39.92 \\
\hline 4 & $\begin{array}{l}\text { Yield gap-I (Potential yield - } \\
\text { Potential farm yield) }\end{array}$ & $7.6(13.22)$ \\
\hline \multirow[t]{6}{*}{5} & $\begin{array}{l}\text { Yield gap-II (Potential farm yield - } \\
\text { Actual yield) }\end{array}$ & \\
\hline & a. Marginal farms & $14.08(28.22)$ \\
\hline & b. Small farms & $12.26(24.57)$ \\
\hline & c. Medium farms & $8.32(16.67)$ \\
\hline & d. Large farms & $5.27(10.56)$ \\
\hline & e. Overall & $9.98(20.00)$ \\
\hline \multirow[t]{6}{*}{6} & Total yield gap (TYG) & \\
\hline & a. Marginal farms & $21.68(37.70)$ \\
\hline & b. Small farms & $19.86(34.54)$ \\
\hline & c. Medium farms & $15.92(27.69)$ \\
\hline & d. Large farms & $12.87(22.38)$ \\
\hline & e. Overall & $17.58(30.57)$ \\
\hline \multirow[t]{6}{*}{7} & Index of yield gap & (in Per cent) \\
\hline & a. Marginal farms & 37.70 \\
\hline & b. Small farms & 34.54 \\
\hline & c. Medium farms & 27.69 \\
\hline & d. Large farms & 22.38 \\
\hline & e. Overall & 30.57 \\
\hline \multirow[t]{6}{*}{8} & Index of Realized potential yield & (in Per cent) \\
\hline & a. Marginal farms & 62.30 \\
\hline & b. Small farms & 65.46 \\
\hline & c. Medium farms & 72.31 \\
\hline & d. Large farms & 77.62 \\
\hline & e. Overall & 69.43 \\
\hline \multirow[t]{6}{*}{9} & $\begin{array}{l}\text { Index of Realized potential farm } \\
\text { yield }\end{array}$ & (in Per cent) \\
\hline & a. Marginal farms & 71.78 \\
\hline & b. Small farms & 75.43 \\
\hline & c. Medium farms & 83.33 \\
\hline & d. Large farms & 89.44 \\
\hline & e. Overall & 80.00 \\
\hline
\end{tabular}

(Figures in parentheses are the respective percentages of yield gap)
The magnitude of average total yield gap worked out to be $17.58 \mathrm{q} / \mathrm{ha}$. This comprised of relatively higher magnitude of yield gap-I $7.6 \mathrm{q} / \mathrm{ha}$, than yield gap-II. The yield gap between the potential farm yield and the actual farm yield were found to be 14.08 quintals, 12.26 quintals, 8.32 quintals and 5.27 quintals per hectare on marginal, small, medium and large farms, respectively with 9.98 quintals per hectare on overall farms.

Table 2: Constraints in rice production (Multiple responses) $n=240$

\begin{tabular}{llll}
\hline $\begin{array}{l}\text { S1. } \\
\text { No. }\end{array}$ & Constraints & $\begin{array}{l}\text { No. of } \\
\text { farmers } \\
\text { responded }\end{array}$ & $\begin{array}{l}\text { Percentage } \\
\text { of farmers } \\
\text { Responded }\end{array}$ \\
\hline 1 & $\begin{array}{l}\text { Insects diseases problem } \\
\text { of particular this variety }\end{array}$ & 168 & 70 \\
2 & $\begin{array}{l}\text { Ineffective weed control } \\
3\end{array}$ & 140 & 58 \\
4 & High cost of insecticide & 147 & 61 \\
5 & $\begin{array}{l}\text { High cost of labor } \\
\text { High cost of herbicide }\end{array}$ & 125 & 52 \\
& $\begin{array}{l}\text { Non-dedication of the } \\
\text { farmers to the farming } \\
\text { activities }\end{array}$ & 116 & 50 \\
$\quad \begin{array}{l}\text { Lack of adoption of } \\
\text { technology such as }\end{array}$ & 112 & 47 \\
$\quad \begin{array}{l}\text { SRI, line sowing and } \\
\text { transplanting }\end{array}$ & $\begin{array}{l}\text { Lack of irrigation facilities } \\
810\end{array}$ & 46 \\
9 & $\begin{array}{l}\text { High price of electricity } \\
\text { bill for tube well }\end{array}$ & 37 & 15 \\
10 & $\begin{array}{l}\text { Problem of label down of } \\
\text { Ground Water }\end{array}$ & 45 & 19 \\
\hline
\end{tabular}

That the percentage of index of yield gap ranging between 22.38 per cent to 37.70 per cent on the large and marginal farms. Index of realized potential yield estimated was, 62.30 per cent, 65.46 per cent, 72.31 per cent 77.62 per cent and 69.43 per cent on the marginal farms, small farms, medium farms large farms and overall respectively. The overall index of realized potential farm yield estimated was 80 per cent and on the marginal small, medium and large farms were 71.78 per cent, 75.43 per cent, 83.33 per cent and 89.44 per cent respectively in the study area. These findings are in conformity with the findings of Kumar et al. (2016); Nirmala et al. (2009); Ashish et al. (2015).

\section{Constraints responsible for yield gaps}

It is observed from the study that there are number 
of constrains, which are responsible for the low productivity or yield gap of paddy variety IGKVR-1 in the study area. Among the major constraints to rice production Insects diseases problem of particular this variety as reported 70 per cent but this variety has the ability to give more yields, followed by high cost of insecticide and ineffective weed control problem as observed by 61 and 58 per cent of the respondents respectively. High cost of labor, high cost of herbicide, non-dedication of the farmers to the farming activities, lack of adoption of technology such as SRI, line sowing and transplanting, lack of irrigation facilities, high price of electricity bill for tube well, lack of marketing facilities, problem of label down of ground water were the other hindering factors in realization of the potential yield (Table 2). Similar types of observation have been were reported in the studies conducted by Job (2006), Nirmala et al. (2009) and Kumar et al. (2016).

\section{CONCLUSION}

To minimize the yield gap some measures requires integrated and holistic approaches and holistic approaches and adequate institutional support to farmers. Mechanization, training programmed adoption of new technology, expansion of surface irrigation (Canal as low cost irrigation method), effective credit facility, effective implementation of crop insurance scheme as well as minimum support prices, along with arrangement for supply of quality seed, fertilizers, insecticides and pesticides etc. to farmers on time are required (Singh and Kumar 2000; Swathi, and Chandrakandan, 2006). They would also require effective extension services to enable them to use recommended level of inputs (Singh, 2010).

\section{REFERENCES}

Babatunde R.O., Salami M.F. and Mohammed B.A. Determinants of Yield Gap in Rain fed and Irrigated Rice Production in Kwara State. 5th International Conference of the African Association of Agricultural Economists Ethiopia. 2016; p153.

Economic Survey of Chhattisgarh.Directorate of Economics and Statistics, Government of Chhattisgarh Raipur 201516.

F.A.O. International rice commission news letter. Food and Agriculture Organization of the United Nation Rome 2013.

Government of India Agricultural Statistics at a Glance, Ministry of Agriculture, Department of Agriculture and Cooperation Directorate of Economics and Statistics, New Delhi 2013.

Job Elsamma Yield gap of rice in Alappuzha district of Kerala. Journal of Tropical Agriculture 2006; p.44 (1-2): 88-90.

Kumar, Santosh, Maury, G.P and Singh, H.P. Yield gap analysis among rice growers of Eastern Uttar Pradesh. International Journal of Agriculture Sciences 2016; 8(15) p1266-1270

Kumar, A., Sinha D.K., Mishra R.R., Ahmad Nasim and Singh K.M. Yield gap analysis of hybrid rice: a case study in Kalyanpur block of Samastipur district Bihar. Journal of Agri Search 2015; p 2(4): 273-276.

Nirmala, B., Jagriti, D., Muthuraman, P., Meera, S.N. and Mangal Sain Yield gap analysis of rice in Raichur district of Karnataka. Karnataka Journal of Agriculture Science, 2009; p 22(1): 238-239.

Singh B.K. and Kumar P. Systematic approach of yield gap analysis in rice production in Ranchi district. Journal of Research BAU. 2000 ;12 (1) p 1-6.

Swathi P.S. and Chandrakandan K. Yield gap analysis among rice growers in north eastern zone of Tamil Nadu." Agricultural Situation in India 2006; 62 (11): p729-733. 